University of Chicago Law School

Chicago Unbound

Journal Articles

Scholarship

2000

The Treaty Power and American Federalism, Part II

Curtis A. Bradley

Follow this and additional works at: https://chicagounbound.uchicago.edu/journal_articles

Part of the Law Commons 


\section{Michigan Law Review}

Volume 99 | Issue 1

2000

The Treaty Power and American Federalism, Part II

Curtis A. Bradley

University of Virginia School of Law

Follow this and additional works at: https://repository.law.umich.edu/mlr

Part of the Constitutional Law Commons, Human Rights Law Commons, International Law Commons, Jurisprudence Commons, Legal History Commons, and the Supreme Court of the United States Commons

\section{Recommended Citation}

Curtis A. Bradley, The Treaty Power and American Federalism, Part II, 99 MICH. L. REV. 98 (2000).

Available at: https://repository.law.umich.edu/mlr/vol99/iss1/4

This Correspondence is brought to you for free and open access by the Michigan Law Review at University of Michigan Law School Scholarship Repository. It has been accepted for inclusion in Michigan Law Review by an authorized editor of University of Michigan Law School Scholarship Repository. For more information, please contact mlaw.repository@umich.edu. 


\title{
THE TREATY POWER AND AMERICAN FEDERALISM, PART II
}

\author{
Curtis A. Bradley*
}

In an article published in this Review two years ago, I described and critiqued what I called the "nationalist view" of the treaty power. Under this view, the national government has the constitutional power to enter into treaties, and thereby create binding national law by virtue of the Supremacy Clause, without regard to either subject matter or federalism limitations. This view is reflected in the writings of a number of prominent foreign affairs law scholars, as well as in the American Law Institute's Restatement (Third) of Foreign Relations Law of the United States. In my article, I argued that this view was, among other things, inconsistent with the limited and enumerated powers structure of the U.S. Constitution. I also argued that this inconsistency was becoming more significant, as the range of treatymaking has expanded and as the Supreme Court has given new life to federalism restraints in the domestic arena.

Recently, Professor David Golove published a 240-page article in this Review that takes issue with much of my analysis. ${ }^{2}$ Invoking constitutional text, structure, precedent, and history, Golove attempts to set forth a broad-based defense of the nationalist view. Notwithstanding our disagreements, there is much in Golove's article that I admire, and it is certainly an important contribution to the debate over the scope of the treaty power. Golove's historical narrative, while not without its difficulties, is particularly enlightening and reflects a prodigious amount of research. Unfortunately, the historical portion of the article is book-ended with discussions that are rather polemical and exaggerated in tone and substance. ${ }^{3}$ More importantly, those who

* Professor, University of Virginia School of Law. For helpful comments and suggestions, I thank Kathryn Bradley, Barry Cushman, Martin Flaherty, Jack Goldsmith, David Golove, Mike Klarman, Julian Ku, Daryl Levinson, Hiroshi Motomura, Bob Nagel, Steve Smith, Paul Stephan, Ted White, and John Yoo. For excellent research assistance, I thank Michael Bell and Cynthia Orchard.

1. Curtis A. Bradley, The Treaty Power and American Federalism, 97 MiCH. L. REV. 390 (1998).

2. David M. Golove, Treaty-Making and the Nation: The Historical Foundations of the Nationalist Conception of the Treaty Power, 98 MICH. L. REV. 1075 (2000).

3. For example, even though the scope of the treaty power has been vigorously debated throughout U.S. history - by serious scholars, prominent public officials, and federal judges - Golove proclaims that "the text and structure of the Constitution, as well as original intent, leave little room for serious debate." Id. at 1078. 
were looking for a full debate between Golove and myself over the scope of the treaty power are likely to be disappointed. Golove's article, even with its historical discussion, largely fails to engage my critique of the nationalist view.

In this reply, I will make four points. First, despite claiming to do so, Golove's article does not in fact defend the nationalist view that I critiqued. Second, Golove's proposed subject matter limitation on the treaty power reflects a false assumption about the views of other foreign affairs scholars and, more importantly, lacks any meaningful content. Third, Golove purports to accept the Supreme Court's recent federalism decisions as a baseline, but much of his analysis is inconsistent with those decisions. Finally, Golove's historical discussion, while rich in detail, is both methodologically inconsistent and tendentious.

\section{ThE "NATiOnAlist ViEW" OF THE TREATy POWER}

In my original article, I coined the term "nationalist view" to refer to the proposition that the treaty power is limited neither by subject matter nor by the reserved powers and rights of the states. ${ }^{4}$ The following statement by Professor Lori Damrosch reflects the view I had in mind: "[T]he treaty-makers may make supreme law binding on the states as to any subject, and notions of states' rights should not be asserted as impediments to the full implementation of treaty obligations." One of the central claims of my article was that the two elements to the nationalist view - the lack of a subject matter limitation and the lack of states' rights limitations - had developed largely in isolation but were now being combined in academic commentary and in the Restatement (Third). ${ }^{6}$ If accepted together, I argued, these two elements of the nationalist view would give the treatymakers essentially unlimited power vis-à-vis the states. I criticized this view as inconsistent with constitutional text and structure, as well as with the Supreme Court's recent federalism decisions.

The principal significance of the nationalist view is that it would allow the treatymakers the ability to circumvent federalism limitations otherwise applicable to the national government's exercise of lawmaking power. Some commentators have suggested, for example, that Congress could reenact the Religious Freedom Restoration Act -

4. Bradley, supra note 1, at 393.

5. Id. (quoting Lori Fisler Damrosch, The Role of the United States Senate Concerning "Self-Executing" and "Non-Self-Executing" Treaties, 67 CHI.-KENT L. REV. 515, 530 (1991)). For other examples of the nationalist view, see RESTATEMENT (THIRD) OF THE FOREIGN RELATIONS LAW OF THE UNITED STATES $\S \S 302,303$ (1987) [hereinafter RESTATEMENT (THIRD)]; LOUIS HENKIN, FOREIGN AFFAIRS AND THE UNITED STATES CONSTITUTION 189-93, 197 (2d ed. 1996); Gerald L. Neuman, The Global Dimension of RFRA, 14 CONST. COMMENTARY 33, 46 (1997).

6. Bradley, supra note 1 , at 423,433 . 
which was invalidated by the Supreme Court on the ground that it exceeded Congress's powers under the Fourteenth Amendment ${ }^{7}$ - as an implementation of an existing treaty commitment. ${ }^{8}$ Similarly, in a recent case involving the Violence Against Women Act, a group of international law scholars filed an amicus curiae brief arguing that, even if the statute exceeded Congress's powers (as the Supreme Court ultimately concluded), it should be upheld as a valid implementation of a treaty. ${ }^{9}$ Commentators also have argued that the treatymakers have the ability to "commandeer" state legislatures and executive officials, notwithstanding Supreme Court decisions disallowing Congress from doing so. ${ }^{10}$

At the end of my article, I considered various constructions of the treaty power that might reconcile the need for flexibility in international negotiations with the structural principles of American federalism. The best contemporary construction, I argued, was one that would allow the treatymakers the ability to conclude treaties on any subject but would limit their ability to create supreme federal law to the scope of Congress's power to do so. This construction would give the treatymakers substantial power to create supreme federal law, while at the same time preventing an end run around the federalism limitations applicable to Congress's creation of such law. ${ }^{11}$ As I acknowledged, my proposed construction would probably require the limiting or overruling of the Supreme Court's 1920 decision, Missouri

7. See City of Boerne v. Flores, 521 U.S. 507 (1997).

8. See, e.g., Neuman, supra note 5, at 52-53; Jeri Nazary Sute, Comment, Reviving RFRA: Congressional Use of Treaty-Implementing Powers to Protect Religious Exercise Rights, 12 EMORY INT'L L. REV. 1535, 1535-38 (1998).

9. Brief of Amici Curiae on Behalf of International Law Scholars and Human Rights Experts in Support of Petitioners at 28-30, United States v. Morrison, 529 U.S. 598 (2000) (Nos. 99-0005, 99-0029). The Supreme Court held that a portion of the Act was invalid because it exceeded Congress's powers; the Court did not mention the treaty argument. United States v. Morrison, 529 U.S. 598 (2000).

10. See, e.g., Martin Flaherty, Are We to Be a Nation? Federal Power vs. "States' Rights" in Foreign Affairs, 70 U. COLO. L. REV. 1277, 1279 (1999); Laurence H. Tribe, Taking Text and Structure Seriously: Reflections on Free Form Method in Constitutional Interpretation, 108 HARV. L. REV. 1221, 1260 (1995); Thomas Healy, Note, Is Missouri v. Holland Still Good Law? Federalism and the Treaty Power, 98 COLUM. L. REV. 1726 (1998); see also Neuman, supra note 5, at 52 (suggesting that the New York anti-commandeering decision may not be applicable to the treaty power); Gerald L. Neuman, The Nationalization of Civil Liberties Revisited, 99 COLUM. L. REV. 1630, 1650-55 (1999) (making same suggestion regarding the Printz anti-commandeering decision).

11. Congress has substantial power, of course, to create supreme federal law in both the domestic and foreign affairs contexts. See, e.g., Crosby v. Nat'l Foreign Trade Council, $120 \mathrm{~S}$. Ct. 2288 (2000) (finding that Congress had preempted a state statute that was designed to restrict trade with Burma). In addition, some treaties do not depend on the creation of supreme federal law for their efficacy, and those treaties would be unaffected by my proposed construction even if they exceeded Congress's powers. $C f$. Head Money Cases, 112 U.S. 580, 598 (1884) ("[A treaty] depends for the enforcement of its provisions on the interest and the honor of the governments which are parties to it."). 
v. Holland, ${ }^{12}$ which upheld the statutory implementation of a migratory birds treaty even though the statute may have been beyond Congress's legislative powers at that time.

Throughout his article, Golove describes himself as defending the "nationalist view" against my critique. ${ }^{13}$ In fact, the view that he defends is, in many respects, narrower than the one I critiqued. Contrary to the conventional academic wisdom that I criticized, Golove accepts the possibility that much of the Supreme Court's recent federalism jurisprudence applies to limit the treaty power, and he also purports to accept a subject matter limitation on the treaty power. The only limitation that Golove specifically argues against is one that would restrict the ability of the treatymakers to create supreme federal law to the scope of Congress's power to do so. In other words, Golove seeks only to defend a narrow version of the Court's holding in Holland. Consequently, his article is not a defense of the nationalist view that I critiqued, but rather is a response to the particular construction of the treaty power I proposed at the end of my article.

Golove begins by acknowledging that "treaties, like all other governmental acts, are subject to the Constitution" and that treaties that violated specific constitutional prohibitions would be unconstitutional. ${ }^{14}$ I would certainly agree, although there is some sweeping language in Holland that could be read to the contrary. ${ }^{15}$ Next, Golove accepts the proposition that treaties are "in principle subject to the separation of powers restrictions which are applicable to ordinary acts of Congress." ${ }^{16}$ Again I agree, although Golove does not adequately distinguish the treaty power's relationship to separation of powers from its relationship to federalism. ${ }^{17}$

12. 252 U.S. 416 (1920).

13. See, e.g., Golove, supra note 2, at 1080 ("In Part I, I set out the basic textual and structural arguments that support the nationalist view."). Occasionally, including in the title of his article, Golove refers to the "nationalist conception." He appears to treat that phrase as synonymous with "nationalist view."

14. Id. at 1083 .

15. Holland, 252 U.S. at 433 ("Acts of Congress are the supreme law of the land only when made in pursuance of the Constitution, while treaties are declared to be so when made under the authority of the United States. It is open to question whether the authority of the United States means more than the formal acts prescribed to make the convention."); see also Thomas Reed Powell, Constitutional Law in 1919-20, 19 MiCH. L. REv. 1, 13 (1920) (noting that the Court's "hint that there may be no other test to be applied than whether the treaty has been duly concluded indicates that the Court might hold that specific constitutional limitations in favor of individual liberty and property are not applicable to deprivations wrought by treaties"). Some of the concerns regarding this language were resolved in Reid v. Cover, in which a plurality of the Court stated that, notwithstanding Holland, the treaty power was limited by the individual rights protections in the Bill of Rights. 354 U.S. 1, 16 (1957).

16. Golove, supra note 2, at 1084.

17. Golove contends that "[n]othing in the constitutional text suggests that treaties are free of the requirements of the separation of powers," Golove, supra note 2, at $1098 \mathrm{n} .53$, 
Most surprisingly, given some of the rhetoric in his article, Golove accepts that "treaties are not immune from federalism limitations." 18 He states, for example, that "[t]reaties have no general license to violate the immunities of states any more than they may violate the rights of individuals. $" 19$ Within such potential federalism limitations, he includes subject matter limitations, the doctrine of state sovereign immunity, and the Supreme Court's recent anti-commandeering limitations. In other words, Golove accepts the possibility that much of the Supreme Court's recent federalism jurisprudence applies to limit the treaty power. Apparently, the only aspect of the Supreme Court's federalism jurisprudence that Golove does not believe applies to the treaty power are the Court's decisions concerning the subject matter scope of Congress's powers under Article I and the Fourteenth Amendment. ${ }^{20}$ At this point, Golove has, perhaps unintentionally, distanced himself from the views of many other commentators concerning the implications of Holland. ${ }^{21}$

but that is also true of the requirements of federalism. The text provides that treaties are the supreme law of the land and that states may not enter into treaties, but it does not provide that there are no federalism limits on the scope of the treaty power. Golove further argues that separation of powers principles are different because they "do not limit the subject matter or content of treaties," but rather "only require that certain subject matters not be regulated in certain ways. ..." Id. at 1097 n.53. To the extent I understand this distinction, it appears to be inaccurate. If separation of powers limitations apply to the treaty power, they prevent treaties from making certain domestic changes (such as the creation of domestic criminal law or the appropriation of money) without the involvement of the House of Representatives. See, e.g., Hopson v. Kreps, 622 F.2d 1375, 1380 (9th Cir. 1980); The Over the Top, 5 F.2d 838, 845 (D. Conn. 1925). Analogously, federalism limitations, if they apply to the treaty power, prevent treaties from making certain domestic changes without the states' consent.

18. Golove, supra note 2 , at 1085.

19. Id. at 1086.

20. Golove argues that these decisions are different from the other federalism decisions because they concern only lack of power, not "affirmative constitutional immunities of states." Id. at 1087. Golove makes a similar distinction in an effort to explain the Supreme Court's use in the nineteenth century of the "equal footing" doctrine to limit the treaty power. Id. at 1231 n.519. As discussed below, Golove's formalistic distinction, which he never defends, appears to be at odds with recent Supreme Court decisions. See infra Part III.

21. See RESTATEMENT (THIRD), supra note $5, \S 302 \mathrm{cmt}$. d (stating that, because of Holland, "the Tenth Amendment, reserving to the several States the powers not delegated to the United States, does not limit the power to make treaties or other agreements"); ERWIN CHEMERINSKY, CONSTITUTIONAL LAW: PRINCIPLES AND POLICIES $\S 3.5 .1$, at 205 (1997) ("The Court [in Holland] ... rejected the claim that state sovereignty and the Tenth Amendment limit the scope of the treaty power."); id. $\S 4.6$, at 273 (because of Holland, "treaties cannot be challenged as violating the Tenth Amendment and infringing state sovereignty"); RONALD D. ROTUNDA \& JOHN E. NOWAK, TREATISE ON CONSTITUTIONAL LAW: SUBSTANCE AND PROCEDURE § 6.5, at 575 (3d ed. 1999) ("Any Tenth Amendment limitation on the federal treaty power was flatly rejected in the landmark case of Missouri $v$. Holland."); Carlos Manuel Vázquez, Breard, Printz, and the Treaty Power, 70 U. COLO. L. REV. 1317, 1343 (1999) ("[U]nless Missouri v. Holland is reconsidered, it appears that there are no limits on the treaty power grounded in state sovereignty."). 
I certainly welcome Golove's partial repudiation of what I have called the "nationalist view." Unfortunately, Golove repeatedly describes his article as if it were presenting a full-fledged defense of that view, which makes his article potentially confusing. For example, he cites scholars and officials as supporting the "nationalist view" when they in fact (at most) supported only one component of it (usually the lack of states' rights limitations). ${ }^{22}$ Similarly, he asserts that the Supreme Court has endorsed the nationalist view, ${ }^{23}$ even though he acknowledges elsewhere that the Court has never held that the treaty power is free from subject matter limitations - and, indeed, that it has suggested just the opposite.

A good illustration of how Golove's use of the term "nationalist view" can be confusing is his treatment of the views of the nineteenthcentury statesman, John Calhoun. Golove relies heavily on statements by Calhoun that suggest the absence of reserved power limitations on the treaty power and argues that these statements show that "Calhoun seems to have accepted the nationalist view of the treaty power."24 Golove does not mention, however, that Calhoun believed in a strong subject matter limitation on the treaty power. In Calhoun's view, the treaty power was to be "strictly limited to questions inter alios; that is, to questions between us and foreign powers which require negotiation to adjust them."25 To extend the treaty power beyond such truly international matters, he said, "would be to extend it beyond its allotted sphere; and, thus, a palpable violation of the constitution." ${ }^{26}$ By contrast, as long as the treaty power was limited to its proper subject matter, Calhoun believed, the treaty power would not unduly threaten the states' reserved powers. Indeed, in his view, the treaty power had rarely, if ever, been used to regulate in areas reserved to the states. ${ }^{27}$ In this context, Calhoun's statements about reserved power limitations

22. See, e.g., Golove, supra note 2, at 1114-15 (Thomas Jefferson); 1140 (James Madison); 1235 (John Calhoun).

23. See, e.g., id. at 1193-1205, 1243-54.

24. Id. at 1235; see also id. at 1091 (quoting Calhoun).

25. John C. CAlhoun, A Disquisition on Government and A Discourse on the CONSTITUTION AND GOVERNMENT OF THE UNITED STATES 203 (Richard K. Cralle ed., 1851).

26. Id.; see also id. at 253 ("[T]he supremacy of laws and treaties is expressly restricted to such as are made in pursuance of the constitution, or under the authority of the United States; which can, in no case, extend beyond the delegated powers.") (emphasis added).

27. See Letter to Henry Wheaton from John Calhoun (June 28, 1844), in XIX THE PAPERS OF JOHN C. CALHOUN 211 (1990) ("From the beginning and throughout the whole existence of the Federal Government [the treaty power] has been exercised constantly on commerce, navigation, and other delegated powers to the almost entire exclusion of the reserved which, from their nature rarely ever come in question between us and other nations."). 
are less surprising. ${ }^{28}$ This example shows why it is inadequate to focus, as Golove does through his redefinition of "nationalist view," on only one aspect of the scope of the treaty power. ${ }^{29}$

Golove's criticisms of my arguments similarly end up getting distorted because of his change in the definition of "nationalist view." For example, he contends that "Professor Bradley claims that Missouri is without historical foundation." ${ }^{30}$ The principal support for this contention is a statement in my article that "the nationalist view of the treaty power is unsupported by history." ${ }^{31}$ I made clear in my article that, however one reads the holding of Holland, it encompasses only part of what I was referring to as the nationalist view. ${ }^{32}$ I did critique Holland, but primarily on nonhistorical grounds. ${ }^{33}$ More generally, Golove errs in repeatedly referring to my critique of the nationalist view as the "states' rights" view,,$^{34}$ and in labeling me a "states' rights advocate." 35 My critique was of an unlimited treaty power, not the lack of states' rights limitations on the treaty power per se.

The problems with Golove's approach go beyond mere terminological confusion. Golove's article is itself another example of the very problem I highlighted in my article: defenders of a broad treaty power artificially divide the subject matter issue from the states' rights issue and defend them separately. The principal tensions between the treaty power and American federalism, however, occur when these two elements of the nationalist view are combined, because it is this combination that would give the treatymakers essentially unlimited power to

28. Moreover, Calhoun actually did believe that there were some (modest) states' rights-related limitations on the treaty power:

[The treatymakers] can enter into no stipulation calculated to change the character of the government; or to do that which can only be done by the constitution-making power; or which is inconsistent with the nature and structure of the government, - or the objects for which it was formed. Among which, it seems to be settled, that it cannot change or alter the boundary of a State, - or cede any portion of its territory without its consent.

CALHOUN, supra note 25, at 204.

29. There are many similar examples of this problem in Golove's article. For example, Golove emphasizes statements in the Jay Treaty debates rejecting states' rights limitations, while neglecting to mention the many statements during the debates suggesting that the treaty power was limited at least by subject matter. $C f$. Bradley, supra note 1 , at $414-15$ (quoting some of these statements); see also Charles A. Lofgren, Missouri v. Holland in Historical Perspective, 1975 SUP. CT. REV. 77, 112 (explaining that there was a "consensus" in the Jay Treaty debates that the treaty power was limited by subject matter).

30. Golove, supra note 2, at 1100; see also id. at 1079 (asserting that "the most recent attacks on Missouri contend that its holding finds no support in history").

31. Bradley, supra note 1 , at 450 (emphasis added).

32. Id. at 429.

33. Id. at 433-50 (critiquing the textual and structural arguments in Holland).

34. See, e.g., Golove, supra note 2, at 1077 n.3, 1279.

35. See, e.g., id. at 1100,1147 n.216, 1188. 
create preemptive federal law. ${ }^{36}$ Nowhere in his article does Golove come to terms with this point. A defense of the "nationalist view," as reflected in the Restatement (Third) and other commentary, has yet to be written.

\section{Golove's PROPOSED SUBJECT MATTER LiMitATION}

As noted above, Golove purports to be accepting a subject matter limitation on the treaty power. Indeed, he proclaims that, "[w]ere the President and Senate to make a treaty on a subject inappropriate for negotiation and agreement, and thus beyond the scope of the treaty power, the treaty would be invalid under the Tenth Amendment." 37 There is, as Golove acknowledges, substantial historical support for a subject matter limitation. To recite just a few examples, James Madison emphasized during the Virginia ratifying debates that "[ $\mathrm{t}] \mathrm{he}$ object of treaties is the regulation of intercourse with foreign nations, and is external;"38 John Calhoun, as noted above, stated in the midnineteenth century that the treaty power was "strictly limited to questions inter alios; that is, to questions between us and foreign powers which require negotiation to adjust them"; 39 and Charles Evans Hughes suggested in 1929 that the treaty power was limited to matters of "international concern" and thus might not allow for the regulation of matters "which normally and appropriately were within the local jurisdictions of the States." 40 Thus, given Golove's emphasis on history, his acceptance of a subject matter limitation is not surprising. It turns out, however, that his proposed subject matter limitation is premised on a false assumption and, more importantly, lacks any meaningful content. ${ }^{41}$

Golove begins by suggesting that the subject matter limitation is a nonissue. He contends that, contrary to the claim in my original article, neither scholars nor the Restatement (Third) have denied the existence of subject matter limitations on the treaty power. ${ }^{42} \mathrm{He}$ is mistaken. As noted above, Professor Damrosch purports to be

36. Bradley, supra note 1 , at 433.

37. Golove, supra note 2 , at 1281 ; see also id. at 1086 ("A treaty that violates this [subject matter] limitation would be beyond the scope of the treaty power and thus would invade the sphere 'reserved' to the states by the Tenth Amendment.").

38. 10 THE DOCUMENTARY HISTORY OF THE RATIFICATION OF THE CONSTITUTION 1396 (John P. Kaminski \& Gaspare J. Saladino eds., 1993) [hereinafter 10 DOCUMENTARY HISTORY].

39. CALHOUN, supra note 25 , at 203.

40. Statement of Charles Evans Hughes, 1929 AM. SOC'Y INT'L L. PROC. 194, 194-96.

41. Golove's proposed subject matter limitation is also ahistorical, a point which I return to in Part IV, infra.

42. Golove, supra note 2 , at 1100 n.61, 1288-90. 
summarizing the state of the law when she states that "the treatymakers may make supreme law binding on the states as to any subject." ${ }^{43}$ Similarly, Professors Barry Carter and Phillip Trimble state in their popular casebook on international law that the constitutional term "treaty" "has come to include any international agreement, $r e$ gardless of subject matter." ${ }^{\prime 4}$ And Professor Louis Henkin has argued that the Constitution's treaty clause "does not imply that an agreement may deal only with certain subjects." ${ }^{45}$

The position of the Restatement (Third) is only slightly more complicated. The first Restatement of Foreign Relations - the Restatement (Second), published in 1965 - had taken the position that the treaty power was limited to matters "of international concern" and further explained that treaties "must relate to the external concerns of the nation as distinguished from matters of a purely internal nature." Restatement (Third) expressly rejects this position, stating that, "[s]ubject to constitutional limitations... the treaty power may be used to make international agreements of the United States on any subject." 47 The "constitutional limitations" referred to, it explains elsewhere, are express constitutional prohibitions, most notably the individual rights provisions in the Bill of Rights ${ }^{48}$ Such provisions may curtail the scope or application of particular treaties, but they do not define the proper subject matter of treatymaking. It seems clear, therefore, that the Restatement (Third) is rejecting a subject matter limitation on the treaty power. Golove suggests that the following statement in the Restatement (Third) reflects a subject matter limitation: "the United States may make an agreement on any subject suggested by its national interests in relations with other nations." ${ }^{39}$ While one could imagine a "national interests" limitation that had content for example, one that disallowed the regulation by treaty of matters of "local" concern - the Restatement (Third) surely was not suggesting such a limitation. Rather, when read in context, the Restatement (Third) was simply once again asserting - in contrast to the Restatement (Second) - that treaties could be concluded on "any subject."

\footnotetext{
43. Damrosch, supra note 5 , at 530 (emphasis added).

44. Barry E. Carter \& Phillip R. TRimble, international LAW 176 (3d ed. 1999) (emphasis added).

45. Louis Henkin, "International Concern" and the Treaty Power of the United States, 63 AM. J. INT'L L. 272, 273 (1969) (editorial comment).

46. RESTATEMENT (SECOND) OF THE FOREIGN RELATIONS LAW OF THE UNITED STATES $§ 117(1)(\mathrm{a}) \& \mathrm{cmt}$. b (1965).

47. RESTATEMENT (THIRD), supra note $5, \S 303 \mathrm{cmt}$. b (emphasis added).

48. Id. $\S 302 \mathrm{cmt}$. b.

49. Id. § $302 \mathrm{cmt}$. c.; see also Golove, supra note 2, at 1290 n.728.

50. Moreover, the sentence in the Restatement (Third) immediately preceding the one Golove quotes invokes international law in a way that directly contradicts Golove's own
} 
Unfortunately for Golove, the problems with his position only begin with the mistaken assumption noted above. Not only have others rejected a subject matter limitation, but, upon close inspection, it turns out that Golove's own proposed subject matter limitation lacks any real content. His position, therefore, actually amounts to a rejection of a subject matter limitation - the very proposition that he denies anyone supports.

Like the Restatement (Third), Golove rejects a subject matter test that would require that treaties address "external" or "international" matters. ${ }^{51} \mathrm{He}$ also rejects limiting the treaty power to the subjects traditionally regulated by treaty when the Constitution was ratified. ${ }^{52}$ Instead, Golove suggests the following subject matter test: the United States can enter into any treaty as long as the treaty is intended to "advance[] the national interests of the United States in its relations with other nations." ${ }^{\text {s3 }}$ Although offered by Golove as a limitation on the treaty power, it is difficult to see how this test would have any limiting force at all. If the President and Senate have decided to enter into a treaty with another nation, they presumably are of the view that it "advances the national interests of the United States" in its relations with that nation. And it seems inconceivable that courts would secondguess this view, which presumably would require an examination of either the national interests of the United States, the subjective beliefs of the U.S. treatymakers, or both. Indeed, if anything is clear from the Supreme Court's foreign affairs and political question jurisprudence, it is that courts are not to engage in such second-guessing. ${ }^{54}$ Golove essentially concedes this point. ${ }^{55}$ Thus, in truth, Golove's "limitation"

proposed subject matter test. Whereas Golove's test would look to the purpose of the U.S. treatymakers, see infra note 53, the Restatement (Third) says: "States may enter into an agreement on any matter of concern to them, and international law does not look behind their motives or purposes in doing so." RESTATEMENT (THIRD), supra note 5 , $\$ 302 \mathrm{cmt}$. c.

51. See, e.g., Golove, supra note 2, at $1289-90$ (stating that the "international" subject matter requirement is "unjustifiable" and has been "widely rejected").

52. See,e.g., id. at 1291 n.730.

53. Id. at $1090 \mathrm{n} .41$; see also id. at $1287,1291 \mathrm{n} .730$. Golove describes this test as his "own interpretation" of the subject matter limitation on the treaty power. Id. at 1287; see also id. at 1090 n.41 ("I interpret this [subject matter] requirement to mean that the President and Senate can make any treaty which advances the national interests of the United States in its relations with other nations.").

54. See, e.g., Regan v. Wald, 468 U.S. 222, 242-43 (1984) (referring to the "traditional deference to executive judgment '[in] this vast external realm' ") (quoting United States v. Curtiss-Wright Export Corp., 299 U.S. 304, 319 (1936)); Haig v. Agee, 453 U.S. 280, 292 (1981) ("Matters intimately related to foreign policy and national security are rarely proper subjects for judicial intervention.").

55. See,e.g., Golove, supra note 2, at 1095 (acknowledging that "the President and Senate have a virtual carte blanche" in determining "the scope of the national interests ... to safeguard and advance through foreign negotiations"); id. at $1262 \mathrm{n} .623$ (noting the "traditional - and continuing - judicial reluctance to second-guess the motives of the political branches, particularly in the field of foreign affairs"); id. at 1292 ("For obvious reasons, 
boils down to the proposition that the treaty power encompasses any treaty that the treatymakers decide to conclude. ${ }^{56}$

This conclusion is confirmed by Golove's discussion of human rights treaties. He repeatedly insists that the civil, political, and other rights of U.S. citizens may be regulated by treaty, notwithstanding his proposed subject matter limitation. ${ }^{57} \mathrm{He}$ tells us that the treatymakers could even regulate local criminal punishment - for example, by entering into a treaty abolishing the death penalty. ${ }^{58}$ Such measures do not exceed the subject matter scope of the treaty power, says Golove, because the treatymakers have decided that human rights issues are important to the United States' international relations. ${ }^{59}$ This claim may be correct, but it confirms that Golove's approach would allow the treatymakers the ability to conclude agreements on essentially any subject they deem appropriate.

Human rights treaties are in fact a likely (and understandable) reason for the Restatement (Third)'s rejection of a subject matter limitation. These treaties regulate the relationship between nations and their own citizens, often on subjects that have historically been considered matters of local concern. Moreover, they are not reciprocal in the traditional sense, in that the incentives to comply with them are not substantially dependent on other nations' compliance. ${ }^{60}$ This latter point has been emphasized in the decisions of a number of international institutions. The International Court of Justice has stated that, with human rights treaties, "one cannot speak of individual advantages or disadvantages to States, or of the maintenance of a perfect contractual balance between rights and duties." ${ }^{\text {61 }}$ Similarly, the Human Rights Committee for the International Covenant on Civil and Political Rights has stated that human rights treaties "are not a web of inter-State exchanges of mutual obligations" and that the "principle of

courts do not feel free to second-guess the political branches on whether a treaty furthers our foreign policy interests.").

56. Like most commentators, Golove would require that there be an actual agreement between nations rather than a "mock marriage." See, e.g., Golove, supra note 2, at 1090 n.41. But, as others have noted, that is not a subject matter limitation. See Henkin, supra note 45, at 274 (stating that the mock treaty limitation "does not suggest any limitations as to the subject matter of treaties").

57. See, e.g., Golove, supra note 2, at 1090 n.41, 1205 n.420,1302-03 n.771.

58. Id. at 1078,1298 n.756. Golove states that such a death penalty treaty "could plausibly be attacked as an abuse of the treaty power," but that, because it would "serve a foreign policy purpose," it would "thus be constitutional." Id. at 1298 n.756.

59. See, e.g., id. at 1092 n.45, 1302.

60. See Jack Goldsmith, International Human Rights Law and the United States Double Standard, 1 GREEN BAG 2D 365, 369-71 (1998) (explaining this point).

61. Reservations to the Convention on the Prevention and Punishment of the Crime of Genocide, 1951 I.C.J. 15, 23 (May 28). 
inter-State reciprocity has no place" in this context. ${ }^{62}$ Regional international institutions have made similar observations. ${ }^{63}$

If the U.S. treaty power were limited to "international" or "external" matters, or to truly reciprocal arrangements, human rights treaties might be suspect. Indeed, this is precisely what a committee of the American Bar Association argued in a widely-discussed 1967 report. ${ }^{64}$ As a result, Professor Henkin, before becoming Chief Reporter for the Restatement (Third), famously challenged such subject matter limitations, expressing concern that they might be interpreted in a way that would undermine U.S. ability to enter into human rights treaties. ${ }^{65}$ And the Restatement (Third) expressly refers to this issue in explaining its rejection of a subject matter limitation, noting that "[e]arly arguments that the United States may not adhere to international human rights agreements because they deal with matters of strictly domestic concern were later abandoned." ${ }^{66}$ Golove appears to be unaware of this recent history. ${ }^{67}$ In any event, his position, fairly read, is quite

62. U.N. GAOR, Hum. Rts. Comm., 52d Sess., 1382d mtg. at 7, U.N. Doc. CCPR/C/21/Rev.1/Add.6 (1994).

63. The Inter-American Court on Human Rights has stated that "modern human rights treaties in general, and the American Convention in particular, are not multilateral treaties of the traditional type concluded to accomplish the reciprocal exchange of rights for the mutual benefit of the contracting States." Effect of Reservations on the Entry into Force of the American Convention (Arts. 74 and 75), Advisory Opinion No. OC-2/82, Inter-Am. Ct. H.R., ser. A: Judgments and Opinions, No. 2, II 29 (1982), reprinted in 22 I.L.M. 37, 47 (1983). And the European Court of Human Rights has described the European Convention on Human Rights as "[u]nlike international treaties of the classic kind" because "the Convention comprises more than mere reciprocal engagements between contracting States." Ireland v. United Kingdom, 25 Eur. Ct. H.R. (Ser. A) at 90 (1978).

64. See Standing Committee on Peace and Law Through United Nations, American Bar Association, Human-Rights Conventions and Recommendations, 1 INI'L LAW. 600, 600-01 (1967).

65. See LOUIS Henkin, Foreign AfFAIRS AND THE CONSTITUTION 152-56 (1972); Louis Henkin, The Constitution, Treaties, and International Human Rights, 116 U. PA. L. REV. 1012, 1014-15 (1968); Henkin, supra note 45 and accompanying text.

66. RESTATEMENT (THIRD), supra note 5, § 302 reporters' note 2 . Of course, the $R e$ statement (Third) uses the passive voice here, leaving it unclear exactly who did the abandoning. But that is another issue. See Bradley, supra note 1, at 432-33. Although Professor Louis Henkin was the Chief Reporter for the Restatement (Third), my criticisms of it do not, as Golove puts it, "call[] Professor Henkin's integrity into question." Golove, supra note 2, at 1290 .

67. Despite insisting that human rights are proper subjects for the treaty power, Golove asserts at times that treaties must involve mutuality and reciprocity. See, e.g., Golove, supra note 2, at 1089, 1093, 1302. On this basis, Golove criticizes Professor G. Edward White for his suggestion that the migratory birds problem in Holland might have been addressed without resort to a treaty. See G. Edward White, The Transformation of the Constitutional Regime of Foreign Relations, 85 VA. L. REV. 1, 71 \& n.246 (1999). According to Golove, White "seems fundamentally to misunderstand the purpose of treaties," which, says Golove, concern "tragedy of the commons" problems that cannot be solved by unilateral acts. Golove, supra note 2, at 1259 n.624. It is Golove, however, who seems to "fundamentally misunderstand" the nature of human rights treaties, since those treaties do not, in fact, concern tragedy of the commons problems. The United States still has strong incentives to protect the human rights of its citizens even if China, for example, fails to do the same. Golove also errs 
similar to Henkin's and the Restatement (Third)'s - that is, he rejects any meaningful subject matter limitation.

Ultimately, Golove ends up retreating to a pure political process limitation on the treaty power, saying that the "remedy for abuse" of the treaty power "lies ultimately in the people and not the courts." 68 criticized this political process argument at length in my original article ${ }^{69}$ and I do not wish to repeat the criticisms here. Instead, I will simply make two general observations. First, even with their requirement of two-thirds senatorial consent, there are some ways in which treaties may be less amenable to the political process argument than domestic legislation. In particular, the negotiation and drafting of treaties is dominated by the Executive Branch, which is not particularly representative of state interests; the treaty process tends to be more opaque, and therefore potentially less open to democratic inputs, than federal legislation; and treaty commitments - particularly in modern, multilateral treaties - are often vague and aspirational, such that their precise consequences, including their consequences for state interests, may become evident only after ratification. ${ }^{70}$ Golove does not address any of these aspects of treatymaking.

Second, the two-thirds senatorial consent requirement does not even apply to executive agreements, which constitute the vast majority of international agreements concluded in recent years by the United States. Golove's only response to this point is to assert that, unlike treaties, executive agreements are not immune from federalism limitations. ${ }^{71}$ He provides no explanation for this assertion, and many of the nationalist commentators he defends have asserted otherwise. In particular, these commentators have claimed that "congressionalexecutive agreements" (executive agreements approved before or after the fact by Congress) are completely interchangeable with treaties and thus can be concluded whenever a treaty could be concluded. ${ }^{72}$

in asserting that "[t]reaties and legislation are of essentially different characters, and to equate them is to make a category mistake of the first magnitude." Id. at 1093. By virtue of the Supremacy Clause, self-executing treaties ratified by the United States have the status of federal legislation. This distinguishes the treaty power from other Article II powers, such as the power to receive and appoint ambassadors. Moreover, under the well-settled "last-intime" rule, treaties are accorded essentially the same domestic law status as federal legislation. Bradley, supra note 1, at 457. Golove's categorical distinction also fails to take account of modern multilateral treaties, many of which resemble and are designed to operate like domestic legislation. Id . at 396-97. Finally, his distinction is at odds with his own position on congressional-executive agreements, which allows statutes to take the place of treaties. See infra text accompanying notes 73-75.

68. Golove, supra note 2, at 1298.

69. Bradley, supra note 1 , at $440-45$.

70. Id. at 442-43.

71. Golove, supra note 2, at 1307-08.

72. RESTATEMENT (THIRD), supra note $5, \S 303 \mathrm{cmt}$. e ("The prevailing view is that the Congressional-Executive agreement can be used as an alternative to the treaty method in 
Golove himself has asserted the same proposition in prior writings. ${ }^{73}$ Indeed, in his article with Professor Ackerman, Golove specifically claimed (like the Restatement (Third)) that congressional-executive agreements are now interchangeable even for purposes of federalism limitations. He explained that, at first, the immunity from federalism limitations allowed in Holland was thought to apply only to Article II treaties, rendering congressional-executive agreements "constitutionally inferior to treaties." ${ }^{\prime 4}$ Through a World War II period constitutional transformation, however, Golove argued that congressionalexecutive agreements became fully interchangeable with Article II treaties. $^{75}$ Whatever the justification, the conventional wisdom is that treaties and congressional-executive agreements are interchangeable, which makes the political process argument even more problematic.

\section{SUPREME COURT'S FEDERALISM DECISIONS}

One reason why the scope of the treaty power has become more important in recent years is that the Supreme Court has revitalized federalism restraints on the national government's power in the domestic arena. This revitalization has taken a variety of forms. Most notably, the Court has limited the reach of Congress's powers under both the Commerce Clause and the Fourteenth Amendment ${ }^{76}$ prohibited Congress from "commandeering" state governments in various ways, ${ }^{77}$ and bolstered state sovereign immunity in both federal and state

every instance." (emphasis added)); id. § $302 \mathrm{cmt}$. d ("[T]he Tenth Amendment, reserving to the several States the powers not delegated to the United States, does not limit the power to make treaties or other agreements." (emphasis added)); HENKIN, supra note 5, at 217 (stating that the congressional-executive agreement "is a complete alternative to a treaty").

73. Bruce Ackerman \& David Golove, Is NAFT A Constitutional?, 108 HARV. L. REV. 799,805 \& n.12 (1995) (citing the Restatement (Third) for the proposition that "there is no significant difference between the legal effect of a congressional-executive agreement and the classical treaty approved by two thirds of the Senate" and stating that the Restatement (Third) "expresses the widely prevailing view"); David M. Golove, Against Free-Form Formalism, 73 N.Y.U. L. REV. 1791, 1799 (1998) ("The longstanding majority view, and the settled practice, is that treaties and congressional-executive agreements, whether ex ante or ex post, are wholly interchangeable." (emphasis added)).

74. Ackerman \& Golove, supra note 73, at 844.

75. Id. at 857-60. This transformation, according to Ackerman and Golove, involved, among other things, a recognition by the Supreme Court of broad unenumerated foreign affairs powers - most notably in Justice Sutherland's opinion for the Court in United States v. Curtiss-Wright Export Corp., 299 U.S. 304 (1936). Id. at 858-59. In his response to my article, however, Golove states that he does "not accept Justice Sutherland's notion of unenumerated foreign affairs powers and [is] skeptical about whether the Court today would still endorse his views." Golove, supra note 2, at 1089 n.36.

76. United States v. Morrison, 120 S. Ct. 1740 (2000); City of Boerne v. Flores, 521 U.S. 507 (1997); United States v. Lopez, 514 U.S. 549 (1995).

77. See Printz v. United States, 521 U.S. 898 (1997); New York v. United States, 505 U.S. 144 (1992). 
courts. $^{78}$ In my original article, I accepted this emerging federalism jurisprudence for the sake of argument, ${ }^{79}$ and I explored the potential implications of that jurisprudence for the treaty power issue. ${ }^{80}$ To avoid confusion, I noted that, like the current Supreme Court, my references to the Tenth Amendment encompassed "any implied constitutional limitation on [the federal government's] authority to regulate state activities, whether grounded in the Tenth Amendment itself or in principles of federalism derived generally from the Constitution." 1

It is of course open to scholars to question the Supreme Court's recent federalism jurisprudence, and many have done so. But this is not Golove's approach. Like me, he purports to accept this jurisprudence for purposes of his analysis. ${ }^{82}$ It becomes clear from Golove's discussion of federalism, however, that he either disagrees with or misunderstands the Supreme Court's decisions. This is evident in at least four respects. First, Golove is dismissive of the tension between an unlimited treaty power and the limited and enumerated powers structure of the Constitution, calling it a "retreat to arguments from first principles." ${ }^{\text {"S3 }}$ Second, Golove repeatedly asserts that the Tenth Amendment is not relevant to determining the scope of the national government's delegated powers and, on this basis, claims that if the treaty power is a separate delegated power (as he argues it is), "no question of 're-

78. See, e.g., Alden v. Maine, 527 U.S. 706 (1999); Seminole Tribe v. Florida, 517 U.S. 44 (1996).

79. See, e.g., Bradley, supra note 1, at 394 ("I am not defending here the value of federalism, or judicial review of federalism, subjects that have generated enormous literature.").

80. I am not alone in raising that question. Professor Erwin Chemerinsky, for example, notes in his recent treatise on constitutional law that "[i]f a particular law violates the Tenth Amendment ... by placing an undue burden on state governments, then it is questionable why the same action would be constitutional if undertaken through a treaty." CHEMERINSKY, supra note 21, at 274. Similarly, a recent casebook on constitutional law lists Missouri v. Holland as a potential candidate for rethinking or overruling in light of the Supreme Court's recent federalism jurisprudence. DANIEL A. FARBER ET AL., CASES AND MATERIALS ON CONSTITUTIONAL LAw: THEMES FOR THE CONSTITUTION'S THIRD CENTURY 850 (2d ed. 1998). For other commentary considering the effect of the Supreme Court's federalism decisions on the scope of the treaty power, see, for example, Flaherty, supra note 10; Vázquez, supra note 21; James A. Deeken, Note, A New Miranda For Foreign Nationals? The Impact of Federalism on International Treaties that Place Affirmative Obligations on State Governments in the Wake of Printz v. United States, 31 VAND. J. TRANSNAT'L L. 997 (1998); Healy, supra note 10; Gavin R. Villareal, Note, One Leg to Stand On: The Treaty Power and Congressional Authority for the Endangered Species Act After United States v. Lopez, 76 TEXAS L. REV. 1125 (1998); and Omar N. White, Comment, The Endangered Species Act's Precarious Perch: A Constitutional Analysis Under the Commerce Clause and the Treaty Power, 27 ECOLOGY L.Q. 215 (2000).

81. Bradley, supra note 1, at 392 n.9 (quoting South Carolina v. Baker, 485 U.S. 505, 511 n.5 (1988) (alteration in original)).

82. Golove, supra note 2, at 1083-88, 1279-86.

83. Id. at 1078. Similarly, Golove dismisses the Founders' emphasis on the limited and enumerated powers principle in a footnote, saying simply that the principle (and other points emphasized by the Founders) "provide[s] little or no interpretive guidance." Id. at 1149 n.222. 
served' powers under the Tenth Amendment can arise."84 Third, Golove sharply distinguishes between the various strands of the Supreme Court's federalism jurisprudence, contending that restrictions on the national government's ability to "commandeer" states and override their immunity from suit (which he accepts may apply to the treaty power) are "an entirely different subject" from limitations on the scope of the national government's lawmaking powers. ${ }^{85}$ Finally, Golove also makes a sharp distinction between the Constitution's treatment of federalism on the one hand and its treatment of separation of powers and individual rights on the other (and on this basis justifies a differential relationship between them and the treaty power) ${ }^{86}$ His position on each of these points is inconsistent with the Supreme Court's recent federalism decisions.

A good starting point for considering the Court's recent federalism jurisprudence is the Court's 1985 decision, Garcia v. San Antonio Metropolitan Transit Authority. ${ }^{87}$ In that decision, a 5-4 majority of the Court largely abandoned judicial enforcement of federalism limitations on the national government's powers. The Court gave very little weight to the Tenth Amendment, mentioning it only once and observing that states retain sovereignty "only to the extent that the Constitution has not divested them of their original powers and transferred those powers to the Federal Government." 88 The Court concluded that "[s]tate sovereign interests ... are more properly protected by procedural safeguards inherent in the structure of the federal system than by judicially created limitations on federal power." 89 In many ways, Golove's view of federalism is similar to the majority's view in Garcia. The Court's federalism jurisprudence, however, has moved a long way since Garcia. $^{90}$

Beginning in 1991, with its Gregory v. Ashcroft decision, ${ }^{91}$ the Court has steadily given content to federalism-based restrictions on the national government's powers. In Gregory, the Court began by emphasizing the "first principles" derided by Golove: that the Constitution created a national government of limited and enumerated powers. ${ }^{92}$ The Court also expressed concern over alterations of the federal-

\author{
84. Id. at 1088. \\ 85. Id. at 1281-82; see also id. at 1086-87. \\ 86. Id. at $1083-84,1285-86$. \\ 87. 469 U.S. 528 (1985). \\ 88. Id. at 549. \\ 89. Id. at 552. \\ 90. See generally John C. Yoo, The Judicial Safeguards of Federalism, 70 S. CAL. L. \\ REV. 1311 (1997) (describing the Court's steady movement away from Garcia since 1991). \\ 91. 501 U.S. 452 (1991). \\ 92. Id. at $457-58$.
}


state balance, especially when the alterations concern matters through which "a State defines itself as a sovereign." these federalism concerns in Gregory by means of a strong "plain statement" rule. It explained that, "inasmuch as this Court in Garcia has left primarily to the political process the protection of the States against intrusive exercises of Congress' Commerce Clause powers, we must be absolutely certain that Congress intended such an exercise." $" 94$

A year later, the Court went further, holding in New York v. United States that it is unconstitutional for Congress to "commandeer" state legislatures. ${ }^{95}$ The Court held that this was true even when Congress is acting "well within" the subject matter scope of the Commerce Clause. ${ }^{96}$ Again, the Court began with the proposition that the Constitution created a national government of limited and enumerated powers. ${ }^{97}$ The Court also, contrary to Golove's view, rejected any sharp distinction between federalism and either individual rights or separation of powers, explaining that, as with its division of power between the federal branches, "the Constitution divides authority between federal and state governments for the protection of individuals." 98

There is, admittedly, some confusing and perhaps inconsistent language in New York about the nature of the Tenth Amendment. In places, the Court suggests that the Tenth Amendment (broadly defined as noted above) operates as a restraint on national power. ${ }^{99}$ In other places, the Court suggests that the Tenth Amendment simply states a "truism" that all powers not delegated to the national government are retained by the states and the people. ${ }^{100}$ And in still other places, the Court suggests that the precise nature of the Tenth Amendment is not important, at least in the case before it. ${ }^{101}$ Golove

\section{Id. at 460 .}

94. Id. at 464 .

95. 505 U.S. 144, 161 (1992).

96. Id. at 173.

97. Id. at 155 .

98. Id. at 181 (emphasis added). Justice Powell had made this same point in his dissent in Garcia:

One can hardly imagine this Court saying that because Congress is composed of individuals, individual rights guaranteed by the Bill of Rights are amply protected by the political process. Yet, the position adopted today is indistinguishable in principle. The Tenth Amendment also is an essential part of the Bill of Rights.

Garcia v. San Antonio Metro. Transit Auth., 469 U.S. 528, 565 n.8 (1985) (Powell, J., dissenting).

99. See, e.g., New York v. United States, 505 U.S. at 188 ("The Constitution . . 'leaves to the several States a residuary and inviolable sovereignty'... reserved explicitly to the States by the Tenth Amendment." (citation omitted)).

100. Id. at 156 (quoting United States v. Darby, 312 U.S. 100, 124 (1941)).

101. See, e.g., id. at 177 ("Whether one views the take title provision as lying outside Congress' enumerated powers, or as infringing upon the core of state sovereignty reserved 
naturally emphasizes the Court's "truism" description. ${ }^{102}$ But this was not the Court's only description of the Tenth Amendment in New York, and New York was not the Court's last decision on the subject. Moreover, the Court in New York, if nothing else, rejected the sharp distinction Golove draws between federalism restrictions based on lack of national power and structural federalism prohibitions on the exercise of national power, calling them "mirror images" of one another. ${ }^{103}$

The Court subsequently extended the holding of New York to prohibit commandeering of state executive officials, in Printz $v$. United States. ${ }^{104}$ The Court concluded that, even though the statute at issue in that case was within the subject matter scope of the Commerce Clause, the measure in question nevertheless "violates the principle of state sovereignty." 105 Again, the Court emphasized the structural principle of limited and enumerated powers. It also stressed the relationship between federalism and separation of powers, and the relationship of both to individual rights. It was obvious by this point that the Court was treating the Tenth Amendment (broadly defined) as a restraint on delegated powers. Indeed, two concurring justices, including the author of the earlier New York decision, stated this expressly. ${ }^{106}$ If there were any lingering doubts about this point, it was cleared up recently in the Court's unanimous decision in Reno v. Condon. ${ }^{107}$ There, the Court stated as follows: "In New York and Printz, we held federal statutes invalid, not because Congress lacked legislative authority over the subject matter, but because those statutes violated the principles of federalism contained in the Tenth Amendment." 108

The "commandeering" decisions are only one strand of the Supreme Court's recent federalism jurisprudence. The Court also has imposed limits on the subject matter scope of Congress's delegated powers - in particular, Congress's powers under the Commerce Clause and under Section 5 of the Fourteenth Amendment. Again, the Court has emphasized the limited and enumerated powers structure of

by the Tenth Amendment, the provision is inconsistent with the federal structure of our Government established by the Constitution.").

102. Golove, supra note 2, at $1280-81$ \& n.702.

103. New York v. United States, 505 U.S. at 156.

104. 521 U.S. 898 (1997).

105. Id. at $923-24$.

106. Id. at 935-36 (O'Connor, J., concurring) ("The Brady Act violates the Tenth Amendment ...."); id. at 936 (Thomas, J., concurring) ("The Court today properly holds that the Brady Act violates the Tenth Amendment ...."). The dissent in Printz argued, like Golove, that the Tenth Amendment "imposes no restriction on the exercise of delegated powers." Id. at 941 (Stevens, J., dissenting).

107. 528 U.S. 141 (2000).

108. Id. at 149 (emphasis added). 
the Constitution. ${ }^{109}$ In light of that structure, the Court reasoned in United States v. Lopez that there must be limits on the scope of the Commerce Clause, and the Court rejected interpretations of that Clause that would allow Congress essentially unlimited power vis-à-vis the states, especially in areas in which the states historically have been sovereign. Similarly, the Court in City of Boerne v. Flores imposed restrictions on Congress's remedial powers under the Fourteenth Amendment, reasoning that "'[a]s broad as the congressional enforcement power is, it is not unlimited." "110

Most recently, in United States v. Morrison, ${ }^{111}$ the Court held that a portion of the Violence Against Women Act was unconstitutional because it exceeded Congress's powers under both the Commerce Clause and the Fourteenth Amendment. The Court first confirmed what it had indicated in Lopez - "that even under our modern, expansive interpretation of the Commerce Clause, Congress' regulatory authority is not without effective bounds." 112 Otherwise, the Court explained, "Congress might use the Commerce Clause to completely obliterate the Constitution's distinction between national and local authority ...."113 In rejecting the dissents' argument that the political process provided sufficient protection against abuses of the commerce power, a majority of the Court once again linked the protection of federalism to the protection of individual rights. ${ }^{14}$ The Court further emphasized the limited and enumerated powers structure of the Constitution, and it concluded that "the Constitution reserves the general police power to the States." 115 As for the Fourteenth Amendment ar-

109. See United States v. Lopez, 514 U.S. 549, 552 (1995); City of Boerne v. Flores, 521 U.S. 507, 516 (1997). Golove dramatically invokes Chief Justice Marshall's famous national power decisions, stating that "few would doubt that Professor Bradley's view is inconsistent with the great opinions of the Marshall Court in, inter alia, McCulloch and Gibbons." Golove, supra note 2, at 1282 n.706. As the Court observed in Lopez, however, McCulloch and Gibbons themselves emphasized the limited and enumerated powers principle. See McCulloch v. Maryland, 17 U.S. (4 Wheat.) 316, 405 (1819) ("This [federal] government is acknowledged by all to be one of enumerated powers."); Gibbons v. Ogden, 22 U.S. (9 Wheat.) 1, 195 (1824) ("The enumeration presupposes something not enumerated...."). The same can be said about another famous Marshall decision. See Marbury v. Madison, 5 U.S. (1 Cranch) 137, 176 (1803) ("The powers of the legislature are defined, and limited; and that those limits may not be mistaken, or forgotten, the constitution is written.").

110. City of Boerne, 521 U.S. at 518 (quoting Oregon v. Mitchell, 400 U.S. 112, 128 (1970) (alteration in original)).

111. 120 S. Ct. 1740 (2000).

112. Id. at 1748.

113. Id. at 1752.

114. Id. at 1753 n.7 ("As we have repeatedly noted, the Framers crafted the federal system of government so that the people's rights would be secured by the division of power.").

115. Id. at 1754 n.8. 
gument in support of the Act, the Court stated again that " [a]s broad as the congressional enforcement power is, it is not unlimited." "116

A third strand of the Court's recent federalism jurisprudence concerns state sovereign immunity. In Seminole Tribe $v$. Florida ${ }^{117}$ the Court held that, even when Congress is acting within the subject matter scope of its Article I powers, it does not have the power to override state sovereign immunity. This is true, the Court held, even when Congress is exercising powers exclusively granted to it and denied to the states - such as the regulation of commerce with Indian Tribes. As the Court stated, "[e]ven when the Constitution vests in Congress complete lawmaking authority over a particular area, the Eleventh Amendment prevents congressional authorization of suits by private parties against unconsenting States." "118 The Court also made clear that the Eleventh Amendment, like the Tenth Amendment, reflects broader principles of state sovereignty than are expressed in the text of the Amendment. ${ }^{119}$

The Court extended the Seminole Tribe decision in Alden v. Maine to hold that states have immunity from federal statutory claims even in state court. ${ }^{120}$ The Alden decision was particularly significant in that it brought together all three strands of the Court's federalism jurisprudence. All of these strands, the Court explained, concern the protection of a system of "dual sovereignty," pursuant to which states have the dignity and authority of sovereigns. The Court stated: "Although the Constitution grants broad powers to Congress, our federalism requires that Congress treat the States in a manner consistent with their status as residuary sovereigns and joint participants in the governance of the Nation." 121 The Court thus denied that its federalism jurisprudence was sharply divided in the way that Golove suggests. ${ }^{122}$ In other

116. Id. at 1755 (quoting Oregon v. Mitchell, 400 U.S. 112, 128 (1970) (alteration in original)). Missouri v. Holland was invoked in Morrison - by the dissent. See id. at 1770 n.18 (Souter, J., dissenting).

117. 517 U.S. 44 (1996).

118. Id. at 72 .

119. Id. at 54 .

120. 527 U.S. 706 (1999).

121. Id. at 748. Like the dissent in Morrison, the dissent in Alden cited Missouri v. Holland. Id. at 807 (Souter, J., dissenting). Shortly before this Article went to print, the Supreme Court decided Solid Waste Agency, Inc. v. United States Army Corps of Eng'rs, No. 99-1178, 2001 U.S. LEXIS 640 (Jan. 9, 2001). In that decision, the Court held that the Army Corps of Engineers had improperly construed a provision in the Clean Water Act as conferring federal authority over isolated, intrastate bodies of water that are used as habitats by migratory birds. $I d$. at *7. That construction of the Act, the Court reasoned, would "raise significant constitutional questions." Id. at *25. The Court noted that it was reaching this conclusion notwithstanding the statement in Missouri v. Holland that the protection of migratory birds is a "national interest of very nearly the first magnitude." Id.

122. The Court also applies federalism-protecting clear statement rules in all strands of its federalism jurisprudence. For recent examples, see Solid Waste Agency, Inc. v. United 
recent sovereign immunity decisions, the Court has continued to analogize federalism protections to individual rights protections. ${ }^{123}$ It has also indicated, albeit in a brief per curiam decision, that the treaty power is limited by state sovereign immunity. ${ }^{124}$

The Supreme Court's federalism jurisprudence is still evolving, with many details not yet resolved. Nevertheless, at least one thing is clear: the Supreme Court's conception of federalism is very different from Golove's conception. Unlike Golove, the Supreme Court places great weight on the limited and enumerated powers principle; views the Tenth Amendment as relevant to the national government's delegated powers; treats the various strands of its federalism jurisprudence as interrelated; and considers federalism limitations to be as important as, and intertwined with, other constitutional limitations. This is a significant flaw in Golove's article, not because the Supreme Court's views are beyond question, but because Golove purports to be accepting them. ${ }^{125}$

\section{GOLOVE'S USE OF HISTORY}

Although my original article had some historical discussion, it was not primarily focused on history. Nor is a reply article the proper place for a detailed historical account. As a result, my goal here is simply to raise some methodological questions about Golove's use of history and to highlight what $I$ believe to be the tendentious nature of Golove's historical narrative.

\section{A. Methodology}

Much of Golove's article is focused on history, including but not limited to Founding history. Golove relies on this history to support specific constitutional arguments regarding the scope of the treaty

States Army Corps of Eng'rs, No. 99-1178, 2001 U.S. LEXIS 640 (Jan. 9, 2001); Jones v. United States, 120 S. Ct. 1904 (2000); and Vermont Agency of Natural Resources v. United States ex rel. Stevens, $120 \mathrm{~S}$. Ct. 1858 (2000). The treaty power has not been immune from such clear statement rules, either before or after Holland. See Guaranty Trust Co. v. United States, 304 U.S. 126, 143 (1938) ("Even the language of a treaty wherever reasonably possible will be construed so as not to override state laws or to impair rights arising under them.") (collecting cases).

123. See, e.g., College Sav. Bank v. Florida Prepaid Postsecondary Educ. Expense Bd., 527 U.S. 666, 682 (1999) ("State sovereign immunity, no less than the right to trial by jury in criminal cases, is constitutionally protected.").

124. See Breard v. Greene, 523 U.S. 371, 376-77 (1998); see also Alden, 527 U.S. at 725 (noting that, when it approved the Eleventh Amendment, Congress considered and rejected an exception for cases arising under treaties).

125. Contrast this with the more defensible approach by Professor Martin Flaherty, who argues that the same scrutiny that I applied in my original article against the nationalist view should be applied to question the Supreme Court's federalism jurisprudence. Flaherty, supra note 10 . 
power. Nowhere in his article, however, does Golove identify his constitutional methodology. The reader is left to wonder whether Golove is advocating a strictly originalist approach to the treaty power question or something else. It is difficult to evaluate Golove's claims and criticisms, however, without knowing his methodological frame of reference. To take one example, Golove asserts that the proposal I set forth at the end of my original article (that the treatymakers' power to make supreme federal law should be limited to the scope of Congress's powers to make supreme federal law) is "entirely extraconstitutional in nature." 126 An evaluation of that charge, however, would require some sense of what Golove believes is "constitutional in nature."

There are suggestions in Golove's article that he assumes that $I$ am an advocate of strict originalism. He declares, as if it were an answer to my article, that "Missouri is an originalist decision." $127 \mathrm{He}$ also accuses me of inconsistency, and even "sleight of hand," because I presented historical support for a subject matter limitation on the treaty power but then ultimately argued against such a limitation. ${ }^{128}$ It is not clear to me why Golove would have assumed I was a strict originalist. As I explained in my prior article, the principal purpose of my historical discussion was to rebut strong claims made by proponents of the nationalist view, not to present an originalist argument for a limited treaty power. ${ }^{129}$ Indeed, the proposal I set forth at the end of my article was presented as distinctly nonoriginalist. As I explained, given changes in the scope of Congress's legislative powers and in the scope and nature of U.S. treatymaking, "the answer to this question [about how federalism should be protected in the treaty context] may be different today than it would have been in the past."130

If Golove is himself advocating strict originalism, then there is a substantial contradiction in his analysis. As discussed above, Golove purports to favor a subject matter limitation on the treaty power. He rejects, however, an originalist subject matter limitation - one that would limit the treaty power to "international," "external," or "traditionally negotiated" matters. Instead, he proffers a "national interests" test, which, as explained above, amounts to essentially no limitation at

126. Golove, supra note 2, at 1310; see also id. at 1279 (describing my proposal as "entirely without support in the Constitution").

127. Id. at 1101; see also id. at 1081 ("Contrary to the speculations of even some of Holmes's most sensitive interpreters, the opinion ultimately rests on standard constitutional premises (text, structure, precedent, and history) - indeed, originalist premises - not on an extraordinary theory of inherent foreign affairs powers or even on a view of the Constitution as an evolving or living text." (emphasis added)). In fact, given that the Court in Holland did not even refer to the Founding materials, Golove is being quite creative in describing it as an originalist decision.

128. Id. at 1288, 1290-91.

129. Bradley, supra note 1 , at 409-10.

130. Id. at 450. 
all. Yet Golove never explains why it is proper to adopt an originalist position with respect to states' rights limitations on the treaty power (assuming he is right about the Founding history) and reject an originalist position with respect to subject matter limitations on the treaty power. He does suggest that a strict subject matter limitation would deprive the treatymakers of needed flexibility in this age of globalization. ${ }^{131}$ Although that may be a strong functional argument, it is hardly an originalist one.

There is, of course, more than one type of originalism. ${ }^{132}$ Some originalists insist that contemporary constitutional interpretation should replicate the precise understandings at the time of the Founding; this is what I am calling "strict originalism." This version of originalism is probably most famously associated with former Judge Bork. ${ }^{133}$ Others argue that those understandings should be "translated" to take account of contemporary conditions. The most famous proponent of this version of originalism, at least in recent years, is Professor Lawrence Lessig..$^{134}$ Still others argue that there have been multiple "Foundings," each of which has changed the meaning of the Constitution. The most famous proponent of this version of originalism is Professor Bruce Ackerman. ${ }^{135}$ In prior writings, Golove has advocated the last type of originalism, which, to borrow a phrase from Ackerman, could be called "constitutional moments" originalism. ${ }^{136}$

Golove does not appear to be relying on constitutional moments originalism in his response to my article, perhaps because he believes that some other constitutional theory is sufficient for his purposes. Interestingly, though, there is a plausible argument that constitutional moments originalism leads to a conclusion contrary to Golove's position. As Professor Peter Spiro has argued, there have been a number of events since World War II that are similar to the events that Golove has in other writings found sufficient to amend the Constitution. ${ }^{137}$ Here is a brief summary of these events:

131. Golove, supra note 2, at 1092 n. 45 .

132. See generally Symposium, Fidelity in Constitutional Theory, 65 FORDHAM L. REV. 1247 (1997) (discussing various types of originalism).

133. Robert H. Bork, The Tempting of America: The Political SEduction of THE LAW 251-65 (1990).

134. Lawrence Lessig, Fidelity in Translation, 71 TEXAS L. REv. 1165 (1993); Lawrence Lessig, Understanding Changed Readings: Fidelity and Theory, 47 STAN. L. REV. 395 (1995).

135. 1 BRUCE ACKERMAN, WE THE PEOPLE: FOUNDATIONS (1991).

136. See, e.g., Ackerman \& Golove, supra note 73; David Golove, From Versailles to San Francisco: the Revolutionary Transformation of the War Powers, 70 U. COLO. L. REV. 1491 (1999).

137. Peter J. Spiro, Foreign Relations Federalism, 70 U. CoLO. L. Rev. 1223, 1271-74 (1999); Peter J. Spiro, The States and International Human Rights, 66 FORDHAM L. REV. $567,576-78(1997)$. 
Before World War II, international law regulated primarily interactions among nations and did not contain extensive individual rights protections. ${ }^{138}$ Soon after the War, with the experience of the Holocaust and other atrocities fresh in mind, the international community began to develop a comprehensive body of international human rights law. The seeds of this law were planted in the 1940s. The United Nations Charter, which came into force in 1945, contained general commitments to protect human rights. ${ }^{139}$ Three years later, the United Nations General Assembly adopted the Convention on the Prevention and Punishment of Genocide and opened it for national ratifications. That same year, the General Assembly issued its nonbinding but nonetheless influential Universal Declaration of Human Rights, which contains broadly worded civil, political, economic, social, and cultural rights. ${ }^{140}$ Immediately following the passage of the Declaration, the United Nations Commission on Human Rights began drafting a human rights covenant aimed at converting the nonbinding provisions of the Declaration into binding treaty obligations. This process eventually led to the promulgation of a number of human rights treaties, including the wide-ranging International Covenant on Civil and Political Rights. ${ }^{141}$ As many international law scholars have noted, the emergence of this human rights law regime constituted a truly revolutionary change in both the nature and scope of international law. ${ }^{142}$

138. See RESTATEMENT (THIRD), supra note 5, pt. VII introductory note, at 144; MARK W. JANIS, AN INTRODUCTION TO INTERNATIONAL LAW 253-57 (3d ed. 1999). For a discussion of the pre-World War II international law protections for human rights, see LOUIS HENKIN, INTERNATIONAL LAw: POLITICS AND VALUES 169-73 (1995).

139. U. N. CHARTER, art. 1, para. 3 (stating that one of the purposes of the United Nations is to "promot[e] and encourag[e] respect for human rights and for fundamental freedoms for all without distinction as to race, sex, language, or religion"); id. art. 55 (stating that the United Nations "shall promote . . . universal respect for, and observance of, human rights and fundamental freedoms for all without distinction as to race, sex, language, or religion"); id. art. 56 ("All Members pledge themselves to take joint and separate action in cooperation with the [United Nations] Organization for the achievement of the purposes set forth in $\mathrm{Ar}$ ticle 55.").

140. G. A. Res. 217(A)(III), U.N. GAOR, 3d Sess., at 71, U.N. Doc. A/810 (1948).

141. The International Covenant on Civil and Political Rights, among other things, grants a right of self-determination, guarantees equal treatment, protects the "right to life" as well as "liberty and security of person," prohibits certain criminal punishments (including certain uses of the death penalty), requires various criminal procedures, limits immigrationrelated measures, bars "arbitrary or unlawful interference with ... privacy, family, home or correspondence," and protects "the right to freedom of thought, conscience and religion" and the "right to freedom of association with others." G.A. Res. 2200A (XXI) U.N. GAOR (1966)

142. See, e.g., Thomas Buergenthal, International Human Rights Law and Institutions: Accomplishments and Prospects, 63 WASH. L. REV. 1 (1988); Louis Henkin, Human Rights and State "Sovereignty", 25 GA. J. INTL. \& COMP. L. 31, 36 (1995-96); John P. Humphrey, The Revolution in the Law of Human Rights, 4 HUM. RTS. 205 (1975); Louis B. Sohn, The New International Law: Protection of the Rights of Individuals Rather than States, 32 AM. U. L. REV. 1 (1982). 
United States officials played a prominent role in initiating this international human rights law regime. Nonetheless, in the 1950s there were intense debates in the United States over whether and to what extent the nation should participate in the regime. The principal subjects of debate were the domestic implications of ratifying international human rights treaties, including the implications for American federalism. As part of these debates, there were numerous proposals to amend the Constitution in order to limit the treaty power. ${ }^{143}$ Along with leaders of the American Bar Association, a key proponent of such an amendment was Senator John Bricker of Ohio, and the various proposed amendments are commonly referred to jointly as the "Bricker Amendment." "144 In general, the proposed amendments were intended to preclude treaties from being self-executing and to make clear that treaties would not override the reserved powers of the states. ${ }^{145}$ Some versions also would have restricted the use of executive agreements. ${ }^{146}$ One of the proposed amendments fell only one vote short of obtaining the necessary two-thirds vote in the Senate. ${ }^{147}$

To help defeat the Bricker Amendment, the Eisenhower administration made repeated commitments that it would not use the treaty power in a way that would infringe on state prerogatives. Secretary of State John Foster Dulles reassured the Senate in 1953 that the administration was "committed to the exercise of the treatymaking power only within traditional limits" and that he did not believe "that treaties should, or lawfully can, be used as a device to circumvent the constitutional procedures established in relation to what are essentially matters of domestic concern." 148 In 1955, Dulles further stated that the administration recognized that the treaty power could not properly be used for matters "which do not essentially affect the actions of nations in relation to international affairs, but are purely internal." ${ }^{149}$ In addition, the State Department published a Circular stating, in obvious reference to the Bricker Amendment debates, that " $[\mathrm{t}]$ reaties are not

143. See, e.g., Treaties and Executive Agreements: Hearings on S.J. Res. 1 and S.J. Res. 43 Before a Subcomm. of the Senate Comm. on the Judiciary, 83d Cong. (1953).

144. See generally NATAlie Hevener KaUfman, Human Rights Treaties ANd THE SENATE (1990); DuANE TANANBAum, THE BRICKER AMENDMENT CONTROVERSY: A TEST OF EISENHOWER'S POLITICAL LEADERSHIP(1988).

145. For example, some versions of the Bricker Amendment provided that "[a] treaty shall become effective as internal law in the United States only through legislation which would be valid in the absence of treaty." TANANBAUM, supra note 144, at 224.

146. For example, some versions of the Bricker Amendment provided that "[e]xecutive agreements shall not be made in lieu of treaties." $I d$. at 222.

147. See TANANBAUM, supra note 144 , at 180.

148. Treaties and Executive Agreements: Hearings Before a Subcomm. of the Senate Comm. on the Judiciary, 83d Cong., 825 (1953).

149. Hearing on S.J. Res. 1 Before a Subcomm. of the Senate Judiciary Comm., 84th Cong., 183 (1955). 
to be used as a device for the purpose of effecting internal social changes or to try to circumvent the constitutional procedures established in relation to what are essentially matters of domestic concern." 150 For decades thereafter, no President attempted even to submit to the Senate major human rights treaties (although they did continue to seek the Senate's advice and consent for the Genocide Convention). Finally, a compromise was reached in the 1970s and 1980s whereby the President and Senate would ratify some of the human rights treaties, but only with a package of limiting conditions, including a federalism clause. ${ }^{151}$ This clause provides that the treaties "shall be implemented by the Federal Government to the extent that it exercises legislative and judicial jurisdiction over the matters covered therein, and otherwise by the state and local governments." 152

Combine this history with a post-Cold War isolationist Senate and the Supreme Court's revival of federalism restraints in the domestic arena, and you might have the makings of constitutional change, at least according to constitutional moments originalism. Perhaps this was what the Clinton Administration had in mind in the recent Breard $v$. Greene ${ }^{153}$ case. There, the International Court of Justice had issued a provisional order stating that the United States was to "take all measures at its disposal" to stay the execution of a Paraguayan inmate on death row in Virginia. ${ }^{154}$ In opposing efforts by Paraguay and the inmate to have the Supreme Court enforce this order, the Justice and State Departments filed a brief with the Court stating that, even if the United States was bound by treaty to comply with the international court's order, "our federal system imposes limits on the federal government's ability to interfere with the criminal justice systems of the States." 155 Strangely, despite his use of the constitutional moments methodology in the past, Golove does not even consider its potential

150. U.S. State Dep't Circular No. 175, para. 2 (Dec. 13, 1955), reprinted in 50 AM. J. INI'L L. 784, 785 (1956).

151. See generally Curtis A. Bradley \& Jack L. Goldsmith, Treaties, Human Rights, and Conditional Consent, 149 U. PA. L. REV. 399 (2000) (describing this development).

152. U.S. Senate Resolution of Advice and Consent to Ratification of the International Covenant on Civil and Political Rights, 102d Cong., 138 CONG. REC. 8071, II II(5) (1992).

153. 523 U.S. 371 (1998).

154. Id. at 374.

155. Brief for the United States as Amicus Curiae at 51, Breard v. Greene, 523 U.S. 371 (1998) (No. 97-1390). In this respect, the circumstances of the Breard case are similar to those of an earlier case involving a different international tribunal. In the mid-1980s, two individuals on death row - one in South Carolina and one in Texas - filed complaints with the Inter-American Commission on Human Rights alleging that their death sentences violated international law. The Commission asked the U.S. State Department to stay the executions while it considered the complaints. The State Department declined to do so, explaining that, under the U.S. federal system, there was no basis for executive branch intervention in the implementation of the sentences. See Case 9647 (Roach \& Pinkerton v. United States), Inter.-Am. C.H.R. 147, OEA/Ser.L/V/II.71, doc. 9, rev. 1, II 11, 18 (1987). 
application to the present issue. Even more strangely, given his writings, Golove strongly criticizes me for proposing that Holland should be limited or overruled, observing that if my proposal were accepted there would be constitutional change "without all the effort" of a formal Article $\mathrm{V}$ amendment - the very thing advocated by constitutional moments originalism. ${ }^{156}$ Of course, Golove's criticism is off the mark in any event, since a constitutional amendment is not needed in order to reassess a Supreme Court decision. But the criticism further highlights the methodological uncertainties underlying Golove's analysis.

\section{B. Law Office History?}

Whatever his constitutional methodology, it is clear that Golove is attempting to avoid the "law office history" charge made against many legal academics who base their arguments on history. ${ }^{157}$ To his credit, Golove has read and considered a vast array of primary and secondary materials, and his article is, as a result, very rich in detail. In addition, he does an admirable job of situating some of the debates over the scope of the treaty power within their historical context. Inattention to detail and context, however, are not the only elements of the law office history charge. A central complaint about the use of history by legal academics (and judges) is that it is shaped and twisted in order to support a particular conclusion. It is in this sense that, notwithstanding its length, Golove's historical discussion may be considered law office history.

Although there is much of interest in Golove's historical discussion, there is also a noticeable one-sidedness to the discussion. There are many manifestations of this. Almost invariably, the historical materials that contradict Golove's conclusion are relegated to footnotes, frequently with a statement that goes something like this: "Unsurprisingly, Professor Bradley relies on this piece of evidence." 158 When Golove encounters statements by officials that support limits on the treaty power, he often asserts that these statements must have been

156. Golove, supra note 2, at 1312 . I should make clear that I am not myself a proponent of constitutional moments originalism, in part because the theory appears to me to be too manipulable, with proponents of this theory finding only the constitutional moments that they like. For this and other criticisms of the theory, see RICHARD A. POSNER, OVERCOMING LAW, ch. 7 (1995); Michael J. Klarman, Constitutional Fact/Constitutional Fiction: A Critique of Bruce Ackerman's Theory of Constitutional Moments, 44 STAN. L. REV. 759 (1992); and Tribe, supra note 10.

157. See, e.g., Martin S. Flaherty, History "Lite" in Modern American Constitutionalism, 95 Colum. L. ReV. 523 (1995); Alfred H. Kelly, Clio and the Court: An Illicit Love Affair, 1965 SuP. CT. REV. 119; John Phillip Reid, Law and History, 27 LOY. L.A. L. REV. 193 (1993); Mark Tushnet, Interdisciplinary Legal Scholarship: The Case of History-In-Law, 71 CHI.-KENT L. REV. 909 (1996).

158. See, e.g., Golove, supra note 2, at 1149 n.22, 1205 n.421, 1225 n.499, 1234 n.528. 
merely tactical or disingenuous, while accepting statements to the contrary (sometimes by the same officials) at face value. ${ }^{159}$ In addition, Golove frequently attaches his own pejorative labels to anyone who has argued for limits on the treaty power. For example, he states that the citizens of South Carolina were not engaging in "[r]ational discussion" when they disagreed with the views of one Supreme Court Justice (William Johnson) concerning the scope of the treaty power, ${ }^{160}$ refers to arguments for restrictions on the treaty power as "states' rights dogmas",i61 and says that efforts in the 1950s to limit the treaty power by constitutional amendment (efforts that received the support of the American Bar Association and many Senators) were "shameful" and involved "virtual fanatics."162 Similarly, Golove often attempts a guiltby-association strategy, suggesting linkages (often no more than temporal) between arguments for a limited treaty power and pernicious practices such as slavery and racial segregation. ${ }^{163}$

Golove is also opportunistic in his use of sources. The reliability of sources in his article often seems to depend on whether they support his views. To take a few examples, he dismisses Madison's construction of the treaty power during the Articles of Confederation period, saying that it "would have seriously undermined Congress's ability to conduct foreign policy;"164 relies on what he perceives to be helpful statements from Madison during the ratification period ${ }^{165}$ and disavows Madison's view of the treaty power during the Jay Treaty debates, suggesting (without much evidence) that Madison was acting as an unwilling front-man for Jefferson. ${ }^{166}$ Similarly, Golove relies on Jefferson's views during the Articles of Confederation period as support for the nationalist view and refers to his "heroic exertions," 167 disavows the views of "the irrepressible Jefferson" during the Jay Treaty debate as reflecting "a legendary hostility to the treaty power,",168 and relies on Jefferson's views and actions as President. ${ }^{169}$ And Golove dismisses John Jay's statements during the Articles of Confederation

159. See, e.g., id. at 1112, 1118-20, 1151 n.225, 1241-42 \& n.552, 1272.

160. Id. at 1222

161. Id. at 1236.

162. Id. at 1274,1275 .

163. See, e.g., id. at 1210-37, 1249-57.

164. Id. at 1111.

165. Id. at $1139-40$.

166. Id. at 1182-83. Golove's main evidence for this assertion is that Madison visited Jefferson's house shortly before writing the statements in question. Id.

167. Id. at $1115,1130-32$.

168. Id. at 1179,1187 .

169. Id. at $1189-93$. 
period as strategic and disingenuous, ${ }^{170}$ while relying on them during the ratification period. ${ }^{171}$ There are many similar examples. ${ }^{172}$

Another problem with Golove's treatment of history is that he often focuses on the treaty power issue in isolation from debates and uncertainties concerning the supremacy of federal law and the scope of other national powers. For example, Golove presents evidence that the Continental Congress entered into treaties beyond its legislative powers, while downplaying the fact that it was unclear during the Articles of Confederation period whether treaties had the status of supreme federal law. ${ }^{173}$ As discussed above, however, it is the creation of domestic federal law beyond Congress's powers that is the ultimate issue in contemporary debates over the scope of the treaty power. In any event, the scope of the national government's legislative powers were uncertain during the Articles of Confederation period, such that it was not always clear whether treaties were in fact exceeding those powers. Thus, for example, John Jay reasoned in 1786 that the debts provision in the treaty of peace with Great Britain did not infringe on the rights of states because the power to confiscate wartime debts rested exclusively with the national government. ${ }^{174}$ Golove disagrees with Jay's reasoning, ${ }^{175}$ but the key point is not whether Jay was right or wrong but that there were uncertainties about the scope of state and national powers, making it unclear whether the treaties were in fact infringing on states' rights.

Similarly, Golove repeatedly relies on treaties granting property rights to alien citizens as proof that the treaty power has historically exceeded Congress's legislative powers, but nowhere in his article does he conclusively show that, after the Constitution was ratified, Congress possessed no power to regulate the property rights of alien citizens. On the contrary, there are repeated hints in Golove's article that this and related issues of congressional power were uncertain and contested throughout the nineteenth century. ${ }^{176}$ Despite these hints, and despite the generally exhaustive nature of Golove's historical nar-

170. Id. at $1117,1120,1150-51 \mathrm{n} .225$.

171. See, e.g., id. at 1137 \& n.178.

172. For example, Golove dismisses Attorney General William Wirt's states' rights views as "a too hasty judgment without adequate consideration and research," $i d$. at 1205 n.421, but later relies on other statements by Wirt that seem more helpful to his arguments, see id. at 1222 n.490; dismisses Edward Livingston at one point, see id. at 1176 n.309, but embraces him at another, see id. at 1225; and relies on Hamilton Fish when he sounds nationalistic, see id. at 1239, but not when he expressly supports states' rights limitations on the treaty power, see id. at 1242 n.552.

173. Id. at 1102-03.

174. Report from John Jay (Oct. 13, 1796), reprinted in 4 SECRET JOURNALS OF THE CONGRESS OF THE CONFEDERATION, at 204 (Boston, Thomas B. Wait 1820).

175. Golove, supra note 2, at 1120 n.120.

176. See, e.g., id. at 1153 n.234, 1216 n.465, 1228 n.510, 1243, 1247. 
rative, Golove does not pursue the issue. ${ }^{177}$ A similar omission occurs in connection with Golove's discussion of South Carolina's Negro Seamen's Act. ${ }^{178}$ Although Golove describes the legal controversy over that Act as if it were primarily focused on the scope of the treaty power, it was in fact primarily focused on the scope of the foreign commerce power, and the materials Golove relies on often invoke Congress's commerce power as the primary basis for invalidating the Act. Justice Johnson did so, for example, in his circuit decision in Elkison v. Deliesseline, ${ }^{179}$ yet Golove unhesitatingly describes him as "invoking the nationalist conception of the treaty power." ${ }^{180}$ Similarly, Golove relies on an opinion on this issue by Attorney General William Wirt as support for the nationalist view ${ }^{181}$ even though the opinion relies primarily on the commerce power. ${ }^{182}$ Golove states that it "seems safe to assume" that Wirt intended his reference to the treaty power to be separate and independent from the commerce power discussion, ${ }^{183}$ but this is questionable in light of the fact that (as Golove notes) Wirt had earlier written an opinion clearly rejecting the nationalist view of the treaty power. ${ }^{184}$

Finally, Golove's description of the historical materials is often exaggerated. For example, he asserts that "states' rights limitations, though sometimes invoked, were uniformly defeated under the [Articles of] Confederation." 185 In fact, there were serious states' rights objections raised against a number of treaties and treaty provisions during this period. These objections were raised by prominent officials, including John Adams, Benjamin Franklin, John Jay, and James Madison, and they led to the delay or nonratification of some treaties, the limitation of others, and the nonenforcement by and against the states of still others. ${ }^{186}$ Even the important Treaty of Peace with Great

177. Golove does not cite a single Supreme Court decision before Holland clearly holding, or even clearly suggesting, that a treaty provision was beyond Congress's legislative powers yet nevertheless valid. Several Supreme Court Justices in Ware v. Hylton, 3 U.S. (3 Dall.) 199 (1796), made such a suggestion, but they were discussing Congress's (much narrower) powers under the Articles of Confederation rather than under the Constitution. Golove, supra note 2, at 1151-53.

178. Id. at 1210-37.

179. 8 F. Cas. 493,494 (C.C.D.S.C. 1823).

180. Golove, supra note 2, at 1216.

181. Id. at $1222 \mathrm{nn} \cdot 490-91$ and accompanying text.

182. See Validity of the S.C. Police Bill, 1 Op. Att'y Gen. 659 (1824).

183. Golove, supra note 2, at 1222 n.490.

184. See Right of Aliens to Hold Property, 1 Op. Att'y Gen. 275 (1819). Wirt's successor, Attorney General John Berrien, also rejected the nationalist view. See 2 Op. Att'y Gen. 426 (1831).

185. Id. at 1139.

186. See, e.g., SAMUEl B. CRANDAll, TREATIES, Their MAKING AND ENFORCEMENT 38-43 (1904); 1 GEORGE TICKNOR CURTIS, History OF THE CONSTITUTION OF THE 
Britain encountered significant states' rights objections. American officials maintained, for example, that the Continental Congress lacked the power to agree to a proposed article in that treaty addressing the issue of confiscated British estates. ${ }^{187}$ As a result, Congress ultimately agreed in the treaty only to recommend to the states that confiscated estates be restored. ${ }^{188}$ It was events such as these that Alexander Hamilton presumably had in mind when he stated in The Federalist that the lack of a commerce power under the Articles of Confederation "has already operated as a bar to the formation of beneficial treaties with foreign powers." 189

Golove also asserts that, during the Founding period, concerns regarding the scope of the treaty power produced only suggestions relating to the process for making treaties and did not produce any suggestions for limiting the substantive scope of the treaty power. "At no point," says Golove, "did concern over the interests of the states lead

UNITED STATES 280-85 (New York, Harper \& Bros. 1860). Contrary to what Golove claims, these states' rights objections were not based on specific limitations in the Articles of Confederation. See Golove, supra note 2, at 1108-11. For example, objections were raised against an alien property provision in a proposed treaty with the Netherlands on the ground that, in James Madison's words, the provision might "encroach on the rights reserved by the federal articles to the individual States." James Madison, Report on Treaty with the Netherlands (July 12, 1782), in 4 THE PAPERS OF JAMES MADISON 411. Subsequently, John Adams decided not to attempt to include the real property component of this provision in the treaty because, as he explained to the Dutch ministers, "Congress had not authority to do this, it being a matter of the interior policy of the separate States." Letter from John Adams to Robert Livingston (Oct. 8, 1782), in 5 THE REVOLUTIONARY Diplomatic CORRESPONDENCE OF THE UNITED STATES 803, 804 (Francis Wharton ed., Washington, Government Printing Office 1889). Neither Madison nor Adams made any reference in these statements to specific limitations in the Articles, and it is hard to see how any of those limitations (which concerned state imposts and duties) would even be relevant. Golove further contends that Congress "disagreed with Adams's constitutional claim," Golove, supra note 2, at 1112-13, but there is nothing in the pages that Golove cites from the Journals of the Continental Congress showing any such disagreement. See id. at 1113 n.92 (citing 24 JOURNALS OF THE CONTINENTAL CONG. 66 (Jan. 23, 1783)).

187. See, e.g., Letter from John Adams, Benjamin Franklin, and John Jay to Richard Oswald, British Commissioner, Nov. 4, 1782, in 1 AMERICAN STATE PAPERS at 219 (Walter Lowrie \& Matthew St. Clair Clarke eds., Washington, Gales \& Seaton 1832) ("[A]s this is a matter evidently appertaining to the internal polity of the separate States, the Congress, by the nature of our constitution, have no authority to interfere with it."). Golove asserts that the American officials were disingenuous in making this claim. The only evidence he offers for this assertion is that the officials ultimately agreed to treaty provisions that appeared to conflict with their claim. See Golove, supra note 2, at 1117-20. There is a difference, however, between insincerity and compromise.

188. See Preliminary Articles of Peace, Nov. 30, 1782, U.S.-Gr. Brit., art. 5, cited in 2 TREATIES AND OTHER INTERNATIONAL ACTS OF THE UNITED STATES OF AMERICA 96, 98 (Hunter Miller ed., 1931) ("It is agreed that the Congress shall earnestly recommend it to the Legislatures of the respective States, to provide for the Restitution of all Estates, Rights, and Properties which have been confiscated, belonging to real British Subjects ...."). $1961)$.

189. The Federalist No. 22 (Alexander Hamilton), at 144 (Clinton Rossiter ed., 
to proposals to restrict the scope of the treaty power." ${ }^{190}$ In fact, this concern led to a number of proposals for clarifying or limiting the scope of the treaty power. For example, the New York resolution of ratification stated that New York was ratifying the Constitution on the understanding that "no treaty ought to operate so as to alter the constitution of any state; nor ought any commercial treaty to operate so as to abrogate any law of the United States."191 A different proposal came from the Virginia and North Carolina conventions. They proposed in their resolutions of ratification that the Constitution be amended to make clear that "no treaty ceding, contracting, restraining, or suspending, the territorial rights or claims of the United States, or any of them, or their, or any of their rights or claims to fishing in the American seas, or navigating the American rivers, shall be made, but in cases of the most urgent and extreme necessity." 192 And Pennsylvania proposed that "no treaty ... shall be deemed or construed to alter or affect any law of the United States, or of any particular state, until such treaty shall have been laid before and assented to by the House of Representatives in Congress," and that treaties shall not be valid if "contradictory to the Constitution of the United States, or the constitutions of the individual states." 193

Golove's claim that the Anti-Federalist charges regarding the potentially unbounded nature of the treaty power were "met with acquiescence, not denial" 194 also overstates (or at least confuses) matters. Golove makes that claim when discussing the Federal Convention. In the Virginia Ratifying Convention, however, which had the most extended debates over the scope of the treaty power, the Federalists strongly disputed the Anti-Federalist charges. George Nicholas argued, for example, that the treatymakers could "make no treaty which shall be repugnant to the spirit of the Constitution, or inconsistent with

190. Golove, supra note 2, at 1135 ; see also id. at 1141 ("Crucially . . this concern [over an unlimited treaty power] did not lead to proposals to limit the scope of the power.").

191. 2 The Debates In The Several State Conventions On The adoption OF THE FEDERAL CONSTITUTION, As RECOMMENDED BY THE GENERAL CONVENTION AT PHILADELPHIA, IN 1787, at 409 (Jonathan Elliot ed., 1866) (amendment proposed July 7, 1788) [hereinafter ELLIOT's DEBATES].

192. 10 DOCUMENTARY HISTORY, supra note 38, at 1554 (amendments proposed by the Virginia Convention, June 27, 1788), and 4 ELLIOT'S DEBATES, supra note 191, at 245 (amendments proposed by the North Carolina Convention, Aug. 1, 1788). The language of both states' seventh proposed amendments were identical in this regard. North Carolina also proposed that no treaties contrary to existing federal statutes should be valid unless and until the statutes were repealed. See id. at 246 (proposed amendment 23). Although Golove refers to the Virginia resolution, he inaccurately describes it as merely procedural in nature. See Golove, supra note 2, at 1141.

193. 2 THE DOCUMENTARY HISTORY OF THE RATIFICATION OF THE CONSTITUTION 598 (Merrill Jensen ed., 1976).

194. Golove, supra note 2, at 1134. 
the delegated powers." 195 Edmund Randolph contended that "neither the life nor property of any citizen, nor the particular right of any State, can be affected by a treaty."196 And James Madison explained that "[t]he exercise of the [treaty] power must be consistent with the object of the delegation" and that "[t]he object of treaties is the regulation of intercourse with foreign nations, and is external." 197 The "external" nature of treaties was crucial, Madison emphasized, because when addressing such matters, the treatymakers "will feel the whole force of national attachment to their country." 198 In light of these statements, as well as the proposed constitutional amendments and clarifications described above, it is difficult to understand the basis for Golove's assertion that "there is only one statement ... in the whole debate over the Constitution - that even arguably supports the states' rights view."199

Golove also overstates the degree to which Supreme Court precedent resolved the treaty power issue prior to Holland. Most of the decisions Golove cites as "affirming the nationalist view" simply held that valid treaties preempt inconsistent state law. ${ }^{200}$ Others failed to address the constitutional relationship between treaties and state law

195. 10 DOCUMENTARY HISTORY, supra note 38, at 1389 (emphasis added). Golove contends that Nicholas was just invoking the standard Federalist argument about why there was no need for a Bill of Rights, Golove, supra note 2, at 1148 , but this misses the point. The standard Federalist argument was that there was no need for a Bill of Rights because the powers delegated to the national government were sufficiently limited in scope that they would not give the national government the ability to take actions that would infringe on individual rights. Bradley, supra note 1 , at 412 \& n.124. By applying that argument to the treaty power, Nicholas was making clear that the Treaty Clause did not give the national government the ability to create preemptive federal law beyond the scope of its delegated legislative powers (and thus potentially infringe on individual rights). Nicholas had made a similar argument earlier in the debate about the Necessary and Proper Clause. 9 THE DOCUMENTARY HISTORY OF THE RATIFICATION OF THE CONSTITUTION 1135 (John A. Kaminski \& Gaspere J. Saladino eds., 1990).

196. 10 DOCUMENTARY HISTORY, supra note 38, at 1385 (emphasis added). In quoting Randolph's statement in the text of his article, Golove places an ellipsis in place of the reference to the rights of states, and relegates that reference to a footnote. Golove, supra note 2, at 1147. In the footnote, Golove contends that Randolph was just referring to the issue of whether a treaty could cede state territory, id. at 1147 n.216, but neither Randolph's statement, nor the statement by Patrick Henry to which he was responding, was limited to that issue. See, e.g., 10 DOCUMENTARY HISTORY, supra note 38, at 1384-85 (statement by Patrick Henry) ("The Constitutions of these States may be most flagrantly violated without remedy.").

197. Id. at 1396.

198. Id. If Golove were correct in suggesting that the Anti-Federalist charges accurately reflected the scope of the treaty power, it would mean that the treaty power would not be subject to any constitutional limitations, since that was one of their charges. See Bradley, supra note 1 , at 413 . But Golove rightly rejects such a construction.

199. Golove, supra note 2 , at 1147 . Golove is referring to the statement by George Nicholas, quoted above.

200. See, e.g., Chirac v. Chirac, 15 U.S. (2 Wheat.) 259, 271 (1817); Ware v. Hylton, 3 U.S. (3 Dall.) 199, 236-37 (1796) (Chase, J.). 
altogether. ${ }^{201}$ Indeed, in many of these cases, the validity of the treaty was not even argued by the parties. A good illustration of Golove's overstatement in this regard is his claim that the Court in Hauenstein v. Lynham ${ }^{202}$ "affirmed all of the essential grounds for the nationalist view." ${ }^{203}$ In fact, the Court in Hauenstein expressly declined to address the scope of the treaty power, noting that "[t]he only point of contention [in this case] was one of construction," and that "[t]here are doubtless limitations of this power as there are of all others arising under such instruments; but this is not the proper occasion to consider the subject." 204 When the Court did refer to the scope of the treaty power in the nineteenth century, it frequently emphasized limitations on that power, including federalism limitations. ${ }^{205}$

It is also inaccurate to suggest, as Golove does, that the only period of American history in which there has been substantial support for states' rights limitations on the treaty power was the period shortly before the Civil War, and that this support largely evaporated after the War. ${ }^{206}$ In fact, although the weight of academic commentary may have come to support a treaty power unrestricted by states' rights prior to Holland, ${ }^{207}$ there were repeated commitments to the states' rights view by U.S. officials all the way up to (and even after) the Holland decision. For example, in a number of instances in the late nineteenth and early twentieth centuries, U.S. officials declined to en-

201. See, e.g., Orr v. Hodgson, 17 U.S. (4 Wheat.) 453 (1819); Fairfax Devisee v. Hunter's Lessee, 11 U.S. (7 Cranch) 603 (1812).

202. 100 U.S. 483 (1879).

203. Golove, supra note 2, at 1244.

204. 100 U.S. at 490.

205. See, e.g., Geofroy v. Riggs, 133 U.S. 258, 267 (1890) (stating that the treaty power could not effect "a change in the character of the [federal] government or in that of one of the States") (emphasis added); Holden v. Joy, 84 U.S. (17 Wall.) 211, 243 (1872) (stating that the treaty power does not extend to subjects "inconsistent with the nature of our government and the relation between the States and the United States") (emphasis added); Holmes v. Jennison, 39 U.S. (14 Pet.) 540, 569 (1840) (stating that the exercise of the treaty power must be "consistent with ... the distribution of powers between the general and state governments"); New Orleans v. United States, 35 U.S. (10 Pet.) 662, 736 (1836) (noting that the federal government is "one of limited powers" and that its authority cannot be "enlarged under the treaty-making power").

206. See, e.g., Golove, supra note 2, at 1078 ("The 'states' rights view' predominated, if ever, only during the antebellum struggle, when the issue became entangled with the slavery question and the accompanying states' rights dogmas of the day."); id. at 1238 ("[T]he nationalist view, in the aftermath of the Civil War, would again gain quick recognition as the dominant construction of the treaty power.").

207. There were, as I explained in my original article, important academic dissenters during this period, most notably Henry St. George Tucker and William Mikell. See HENRY St. GeORge TUCKer, Limitations ON THE TREATY-Making POWER UNDER THE CONSTITUTION OF THE UNITED STATES (1915); William E. Mikell, The Extent of the Treaty Making Power of the President and Senate of the United States (II), 57 U. PA. L. REV. 528 (1909). In addition, many academic commentators who rejected states' rights limitations appeared to believe in subject matter limitations. See Bradley, supra note 1, at 421-22. 
ter into negotiations concerning private international law treaties because of a concern that the treaties would infringe on the reserved powers of the states. ${ }^{208}$ Similarly, even as late as a few years before Holland, U.S. representatives insisted that they could not agree to a treaty regulating certain labor conditions because those matters were within the reserved powers of the states. ${ }^{209}$ These states' rights concerns continued to inhibit U.S. participation in private international law, labor, and other treaty regimes even after Holland. ${ }^{210}$

\section{CONCLUSION}

The scope of the treaty power has been debated numerous times throughout this nation's history. The issue has resurfaced in recent years for a number of reasons, including the Supreme Court's revitalization of federalism restraints in the domestic arena and an expansion in the scope and range of U.S. treatymaking. As I explained in my original article, these and other changes have heightened the potential conflict between the treaty power and American federalism. This conflict is posed most squarely by what I have called the "nationalist view" of the treaty power, which would allow the treatymakers the ability to create supreme federal law without regard to either subject matter or federalism limitations. The nationalist view can be criticized on a number of grounds, not the least of which is that it appears to conflict with the limited and enumerated powers structure of the Constitution.

Despite its length and detail, Golove's article is largely unresponsive to my critique. The article is off-track right from the beginning, with its unexplained redefinition of the term "nationalist view." It then runs into serious analytical difficulties when it tries to both embrace and reject a subject matter limitation on the treaty power and tries to both embrace and reject the Supreme Court's recent federalism juris-

208. See Kurt H. Nadelmann, Ignored State Interests: The Federal Government and International Efforts to Unify Rules of Private Law, 102 U. PA. L. REV. 323 (1954); see also HAROLD W. STOKE, THE FOREIGN RELATIONS OF THE FEDERAL STATE 187-88 (1931).

209. See James T. Shotwell, Historical Significance of the International Labour Conference, in LABOUR AS AN INTERNATIONAL PROBLEM 41 (E. John Solano ed., 1920); see also STOKE, supra note 208 , at 189.

210. See Pitman B. Potter, Inhibitions Upon the Treaty-Making Power of the United States, 28 AM. J. INT'L L. 456 (1934). The fact that U.S. treatymakers perceived federalism limits on their ability to enter into labor treaties after Holland also tends to undermine one of Golove's most surprising claims: that the Court in Holland was self-consciously inviting the federal government to use the treaty power to circumvent the Court's earlier decision in Hammer v. Dagenhart, 247 U.S. 251 (1918), in which the Court had held that a child labor statute unconstitutionally invaded the reserved powers of the states. Golove, supra note 2, at $1080,1269,1304$. Further undermining Golove's claim is the fact that the Court reaffirmed Hammer two years after Holland and specifically held that Congress could not use its taxing power to circumvent the Hammer decision. Bailey v. Drexel Furniture Co. (The Child Labor Tax Case), 259 U.S. 20, 39 (1922). 
prudence. Although Golove's historical research is an important contribution to the debate, it is plagued by methodological inconsistencies, and the tendentious and exaggerated way in which it is presented undermines its reliability. More fundamentally, Golove's article fails to appreciate the legitimate reasons why the treaty power question has been a persistent feature of American political and legal discourse, and why, in this age of globalization, the question once again merits our attention. 